\title{
Impact of Various Drainage Technologies on Yield and Yield Components of Wheat (Triticum aestivum), Improving Water Harvesting and Water Productivity
}

\author{
Eyerusalem Hailu ${ }^{1}$, Melese Temesgen ${ }^{2}$ and Thomas Abraham ${ }^{1 *}$
}

${ }^{1}$ Department of Plant Sciences, College of Agriculture \& Veterinary Sciences, Ambo University, Ethiopia, P.O. Box -19

${ }^{2}$ Researcher, Addis Ababa University, Ethiopia

*Corresponding author: drthomasabraham7@gmail.com (ORCID ID: 0000-0002-3241-5038)

Paper No. 784

Received: 10-04-2019

Revised: 13-07-2019

Accepted: $19-08-2019$

\begin{abstract}
Vertisols account for about 70 percent of all highland soils with slopes between 0 and 8 percent in Ethiopia. The high clay content of the Vertisols is responsible for their heavy water logging in highland areas with abundant rainfall and low infiltration rates which imposes severe restrictions on the traditional agricultural use of these soils and only 25 percent are currently cropped, mainly using residual moisture. Much of this land is left fallow and subject to erosion during the heavy rains. This study evaluated the performance different drainage technologies for wheat (Triticum aestivum) and water use efficiency on field plot in 2015 at Ginchi district, west Shoa Zone of Oromia Regional State. Four treatments such as drainage technologies (Aybar BBM (Broad Bed Maker), Shaga, Shurube and control) were laid out in Randomized Complete Block Design (RCBD). Traditional technologies has extended the duration of the growing period of wheat on average by 6 days from 93 days under the Aybar BBM to 99 days in control. Aybar BBM increased grain yield of wheat from $2318.21 \mathrm{~kg} \mathrm{ha}^{-1}$ from the control to $4652.45 \mathrm{~kg} \mathrm{ha}^{-1}$, while dry biomass was increased by $28 \%$ as compared to the control. Existing moisture chickpea (Cicer arietinum) was harvested and using Rain water harvesting in the pond root beet (Beta Vulgaris) and carrot (Daucus carota) were harvested as a triple cropping in the same field plot. Therefore, it was concluded that new drainage technologies in vertisols such as Aybar BBM re-enforced by water harvesting increased the gross crop yield and double as well as triple cropping can be achieved.

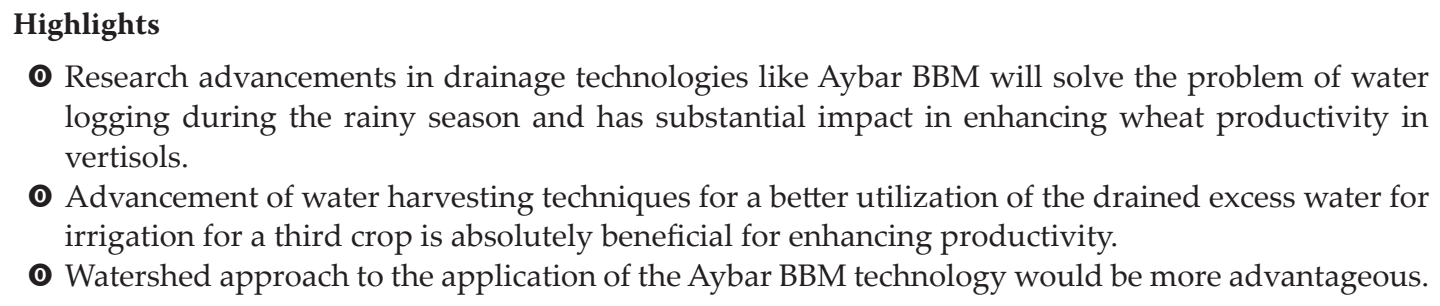

Keywords: Vertisol management, Rain water harvesting, Wheat, Cropping practices, Aybar BBM

Rain-fed agriculture contributes the largest share in the total agricultural production in Ethiopia and this is expected to continue in the foreseeable future as indicated in the sustained increase in land area under rain-fed farming (Sileshi et al. 2011).

From an estimated global 300 million ha of Vertisols, 43 million ha are located in tropical Africa. An additional 80 million ha of soils with 'vertic' properties require similar management as Vertisols for exploiting its agricultural potential (Virmani, 1988). Ethiopia ranks third in Vertisols abundance in Africa after the Sudan and Chad (Birhanu Debele, 1985). An estimated 7.6 million ha of Ethiopian Vertisols are located in the highlands above 1500 
$\mathrm{m}$ a.s.l. and on higher elevations (> 2500 m.a.s.l.) in temperate ecosystems (Birhanu Debele, 1985; Jutzi and Mesfin, 1987; Lakew et al. 2005; Teklu et al. 2006). The highlands cover $40 \%$ of the total landmass of the country but account for about $95 \%$ of all cultivated land. Hence, the importance of Vertisols in the country is unquestionable.

However, most of the Vertisols suffer from excess water and poor workability and are also underutilized, and largely used for dry season grazing (Srivastava et al. 1993). Potentially, Vertisols are productive soils, but they are not easy to cultivate due to their poor internal drainage and resultant flooding and water logging during the wet season which contribute for lower crop yields. About 2 million hectares of highland Vertisols are currently being cropped. This means presently only $25 \%$ of the 7.6 million hectares Vertisols in the highlands are cultivated (Rutherford et al. 2001).

Wheat (Triticum aestivum) is one of the major food crops with low productivity in Ethiopia. It is the second important cereal crop with annual production of about 3.43 million tons cultivated on area of 1.63 million hectares (CSA, 2013). Most parts of the highlands generally receive adequate amount of rainfall in normal years, which eventually drains into lakes and rivers. Unfortunately, much rainwater is lost in absence of adequate conservation and harvesting activities. Rainwater harvesting can be broadly defined as a collection and concentration of runoff for productive purposes like crop, fodder, pasture or trees production, livestock and domestic water supply (Ngigi, 2003).

Ginchi district Dendi woreda soil is characterized by vertisol and endowed with ample water resource and receives abundant rainwater. However, traditionally farmers use low yielding crop varieties and do not usually apply improved surface drainage practices. However some farmers use ridges and furrows, late planting, handmade broadbeds wit furrows, and soil burning practices to solve water logging problems. The low level of rain water harvesting for crop production observed at the national level is also seen here. The problem is aggravated due to the fact that the majority of the farmers are highly dependent on traditional farming system and rain-fed agriculture.

In an attempt to increase agricultural productivity and improved food security at both national and household level, efforts have been underway to generate and disseminate improved agricultural technologies among smallholder farmers. The productivity of Vertisols can be increased by surface drainage. Broadbeds and furrows (BBFs) made with low-cost, animal-drawn implements help drain excess water (Jutzi et al. 1986), thus enabling farmers to plant crops early in the main rainy season. Run-off rainwater can be conserved in ponds or reservoirs (Abiye et al. 1986) and used to irrigate the land for a second crop even for triple cropping.

Vertisols has good potential to provide favorable conditions for high crop productivity. Vertisols are productive, provided there is good aeration for the respiration of crop roots. However, Vertisols in the study area are usually water-logged during the rainy season. Therefore, draining out excess water through providing optimum drainage facilities is the way out to make Vertisols highly productive. Effective management of Vertisols in the region is very crucial due to their poor drainage and resultant flooding and water logging during the wet season. Consequently, Vertisols in Ethiopia are currently underutilized, and largely used for dry season grazing. The cultivated Vertisols give low yields, and are exposed to soil erosion because the fields are ploughed before the main rains and, sown towards the end of the rainy season to avoid water logging. While Vertisols remain underutilized, population pressure has pushed crop production and livestock grazing to steep slopes causing serious de-vegetation and soil erosion. Therefore, in food deficit Ethiopia, removing constraints to crop production in vertisol areas is of very high importance (Tekalign et al. 1993).

The inherent management problem occurs due to water logging caused by the slow percolation rates of these soils coupled with low evaporation for tapping their agricultural potential in the highlands. Compared to the drainage problem, erosion caused by the runoff from the higher landscape and from draining off the excess water can exacerbate soil erosion, especially gully erosion, which is another major problem of these soils in the highlands (Morgan, 1972).

Despite improvements in crop productivity, farmers did not widely adopt the Aybar BBM citing heavy weight of the implement, lack of stability during operation and other reasons. Recently, a new type 
of BBM called Aybar BBM has been developed. Field evaluation of the Aybar BBM by farmers in different parts of the country showed that Aybar BBM is lighter, requires less draft power, it is stable during operation and it gives higher crop yields, among others compared to the old AybarBBM (Rutherford AS, 2008). Scientific research to validate the responses of wheat to surface drainage by using Aybar technology and harvesting water from drained farms in specific place at Ginch area needs further study.

The aim of the study was to assess the performance of wheat influenced by different drainage technologies. The study particularly targeted to determine the effect on surface drainage of Vertisols using different technologies such as Aybar BBM, Shaga and Shurube on the yield and yield components of wheat. Further goal of the research was to investigate the benefits of integration of surface drainage with water harvesting ponds on crop yields and water productivity and to study the economics of applying surface drainage technologies on Vertisols at Ginchi district. The study was conducted in Ginchi district, which is found in West Shoa Zone, and a representative site for the vertisol in Ethiopia. The study explored differential impacts of surface drainage of vertisol using different technologies on wheat yield and yield components and water harvesting performance on double and triples cropping.

\section{MATERIALS AND METHODS}

The experiment was conducted in Dendi district; one of the districts found in West Shoa zonal administration; Oromia National Regional State in 2016. Dendi is one of the eighteen districts in west Shoa Zone, and located at $76 \mathrm{~km}$ West of Addis Ababa; the capital city of Ethiopia, and $40 \mathrm{~km}$ to the East of Ambo town; zonal city of West Shoa. The district is bordered by Wonchi district in the South, by Ambo district in the West, by Jeldu district in the North by Ejere district in the East, and by Dawo district of South West Shoa Zone in the South East (CSA, 2013).

Dendi district is divided into different altitudinal ranges: 29\% high land altitude (Dega) and 71\% mid altitude (Weyna-Dega). There are 47 rural peasant associations (PAs) and 6 urban kebeles in the district with an average altitude between 2,000 meters to 3,288 meters above sea level (CSA, 2013).

The design used for this field experiment was Randomized Complete Block Design (RCBD) with four treatments and three replications. Single plot size of the experiment was of $40 \mathrm{~m}$ length and $7.5 \mathrm{~m}$ width. Hence, total plot number of the experiment was twelve (four $\times$ three). The treatments were assigned randomly to the plots within a block.

The design used for this field experiment was Randomized Complete Block Design (RCBD) with four treatments and three replications. Single plot size of the experiment was of $40 \mathrm{~m}$ length and $7.5 \mathrm{~m}$ width. Hence, total plot number of the experiment was twelve (four $\times$ three). The treatments were assigned randomly to the plots within a block.

The four treatments such as drainage technologies Aybar BBM (which is a latest technology in surface drainage using Broad Bed Maker), Shaga (traditional method of bed making with bushy material attached to the traditional plough), Shurube (also a traditional method of furrow making by traditional plough (Maresha) and control (traditionally practised by some farmers which is direct sowing without draining water). The four treatments were laid out in Randomized Complete Block Design (RCBD).

The experimental field was ploughed with oxen drawn plough as per the recommended tillage practice for the wheat crop (three times before sowing) to have good and uniform crop stand. According to the design, field layouts were made and each treatment was assigned randomly to the experimental units within a block.

\section{Sowing}

Before seedbeds were prepared, Kakaba wheat variety was sown at the recommended rate of 150 $\mathrm{kg}$ seed ha-1 manually by broadcasting method in June $27 / 2015$, before the application of the different drainage technologies

\section{Fertilizer application}

The fertilizer application was done based on the recommended rates of $100 \mathrm{~kg}$ DAP and $100 \mathrm{~kg}$ UREA per hectare.

\section{Weeding, harvesting and threshing}

Weeding, harvesting and threshing were carried out 
manually (physically and mechanically) according to the farmers' practices and chemical herbicides and pesticides were applied to avoid sudden occurrence of weeds and diseases on the crop. Therefore weeding was done at 3 and 4-6 weeks after planting.

All data requiring laboratory analysis 1000 seed weight (gm) and straw yield were conducted at Ambo University.

\section{Soil sampling and analysis}

Soil samples were taken from the experimental site for laboratory analysis. Laboratory services were obtained from Ambo University Agriculture laboratory for texture and bulk density and $\mathrm{pH}$ analysis. Soil $\mathrm{pH}$ was measured potentiometrically using a digital $\mathrm{pH}$ meter in a 1:2 soil to water ratio suspension (Van Reeuwijk, 1992)

\section{Bulk density (BD)}

Soil bulk density was determined on undisturbed soil samples following the core sampling method. Bulk density was then calculated from the measurement of the bulk volume, using the core length and the diameter of the cutting edge of the sampler (Eq. 1).

Mathematically it is expressed as;

$$
\begin{aligned}
\mathrm{BD}= & (\text { Weight of dry sample }(\mathrm{g})) /(\text { Volume of } \\
& \text { sample } \left.\left(\mathrm{cm}^{3}\right)\right)
\end{aligned}
$$

\section{Texture analysis}

The soil texture analysis for the study site was determined from disturbed soil samples. The particle size analysis using hydrometer method and the texture groups were determined by USDA textural triangle chart. Soil sample was taken from the surface of the study area.

\section{Digging of ponds and installation of equipment}

Ponds were dug at the lowest point of the catchment based on topographic surveys. One pond with the standard size of $130 \mathrm{~m}^{3}$ used for the study (Fig. 2 and $3)$. Excess water drained from plots was led to the ponds with appropriate silt traps dug close to the ponds. The ponds were lined with geo-membranes.

At the centers of each pond a graduated bar was placed so as to monitor water levels. A flow measuring trough was also placed at the lowest point near the pond to measure the amount of water flowing out of the pond. Two manual rain gauges were installed near the experimental plots for daily measurement of rainfall.

Dimension of trapezoidal pond in the study area shows as follows:

$$
V=\frac{H}{3}(A t+A b)+\sqrt{A t^{2}+A b^{2}}
$$

Whereas: V: storage capacity, $\mathrm{m}^{3}$

$H$ : water storage depth, $m$

At; width at the top, $m$

$A b$ : width at the bottom, $m$

\section{Runoff Harvesting Efficiency (RHE)}

Can be measured as the ratio of the amount of water collection and diversion mechanism of the system. Losses during harvesting can be minimized by proper management of the catchment and diversion channel. It can be mathematically expressed as follows (Suresh, 1997):

$$
R H E=\frac{\text { Water harvested }}{\text { Total runof } f}=\frac{\text { Runof } f \text { harvested }}{P^{*} C^{*} A}
$$

Where: $P$ is design rainfall; $C$ is runof $f$ coefficient and $A$ is catchment area

\section{Runoff Storage Efficiency (RSE)}

Is the ratio of the amount of runoff available in the storage to the amount of runoff input, which actually gets into the storage unit. The ratio can be one if and only if no seepage and evaporation losses occur in the pond. This can be expressed as (Suresh, 1997):

$$
\begin{gathered}
\text { RSE }=\frac{\text { Water input }- \text { Losses }}{\text { Water input }}= \\
\frac{\text { Water consumed }+ \text { Water in the storage }}{\text { Water input }}
\end{gathered}
$$

\section{System Efficiency (SE)}

It measures the effectiveness of the whole system that indicates how much of the runoff produced on the catchment of rainwater harvesting systems is consumed for irrigation or any other purpose. It is calculated as follows (Suresh, 1997): 


$$
S E=\frac{\text { Water consumed }+ \text { Water in the storage }}{\text { Total runof } f}
$$

\section{Water productivity (WP)}

Is the ratio of the physical yield of a crop $(\mathrm{kg})$ and the amount of water consumed $\left(\mathrm{m}^{3}\right)$, including both rainfall and supplemental irrigation (Arega Yimer, 2003).

$$
W P=\frac{\text { Yield }}{\text { Amount of water consumed }}
$$

\section{Catchment area}

The water which is stored in the pond was collected and harvested from different farm plots. On average, the size of the catchment for system was 0.8 ha and the dominant land use type was cultivated land.

\section{Diversion channels}

In the study area for there was various diversion earthen channel used for diverting and conveying the runoff from the catchment to the silt trap or directly to the storage. The diversion channel was standard in size with an average width of $0.26 \mathrm{~m}$ and depth of $0.20 \mathrm{~m}$. These channels were constructed by Aybar BBM during planting.

\section{Silt trap}

The silt trap reduced the sedimentation on average by $11.25 \%$ in the study area. According to Tekeste Hailemariam (2012) the efficiency of these silt traps was measured in nearly 9 ponds and it was found that they reduced sedimentation on average by $10.53 \%$. Based on the observation the ponds had little sediment that could easily be removed manually and siltation was not seen as a serious problem by DAs. Some of the dried ponds had a sediment load of nearly $3.5 \mathrm{~cm}$ thick.

\section{Storage ponds (Trapezoidal rainwater harvesting tank)}

The storage capacity design of trapezoidal structure in the study district had $130 \mathrm{~m}^{3}, 8 \mathrm{~m}$ by $8 \mathrm{~m}$ top area and $3 \mathrm{~m}$ by $3 \mathrm{~m}$ bottom area and $3 \mathrm{~m}$ depth (Dendi woreda Agricultural office (unpublished), 2015. The construction of the structure was done with different storage capacity and construction materials depending on the volume of water harvested and availability of construction materials. In Ginchi districts geo-membrane plastic sheet with the size of $13.5 \mathrm{~m} \times 13.5 \mathrm{~m}$ was used for lining the floor and wall of the storage pond after excavation of the soil. The plastic was placed on to well-shaped and smooth surface trapezoidal shaped rainwater storage. One meter length of excess plastic was extended on which stones were placed at mouth of the storage pond in order to fix it with the ground. The plastic sheet was purchased from Addis Ababa and it was cut and welded in the region (Ginchi and the rest in Addis Ababa) to fit the size of the trapezoidal structure.

\section{Irrigated area}

Based on the data from study area the land which is irrigated was the same as that of the land used for wheat in Farmers Training Center (FTC) and the land was 0.03ha. But according to Oromia Bureau Agriculture (BOA, 2003) the design was normally to irrigate 0.043 ha of land by using storages with the capacity of $130 \mathrm{~m}^{3}$ (trapezoidal). However, the water was not done as per the plan because the land in the FTC was limited to demonstration work only. The slope of the surveyed land was three (3) percent and the texture of the soil was clay. The dominant crop planted was chickpea as double crop and vegetables carrot were directly planted and root beet was transplanted from other area which was nearer to that field plot.

\section{Crop data collection}

Days to $50 \%$ wheat flowering was taken as the time from the date of planting until half of the plant populations in the farm plot started to flower. Similarly, days to maturity for wheat was taken as the time from date of planting until $90 \%$ of the plants in a plot reached physiological maturity based on visual observation.

\section{Crop growth parameter}

Plant height was measured at maturity, from ten random selected plant samples of the harvestable by Aybar BBM, Shaga, Shurube and Control field plots, from the ground level to the tip of the spike. For the experiment on wheat, biomass or biological yield was measured by weighing the total above 
ground plant biomass within each treatment; the numbers of fertile tillers were determined by counting the tillers from an area of $1 \mathrm{~m} \times 1 \mathrm{~m}$. sampling sites were randomly selected by throwing a quadrant into the middle portion of each plot at physiological maturity. Grain yield (kg/hectare) was measured by taking the weight of the grains threshed from each treatments field plot and converted to kilograms per hectare after adjusting the grain moisture content to $12.5 \%$. One thousand kernels weight was measured by weighing 1000 seeds from the harvest.

Adjusted yield developed by (Dickey- john) was calculated as:

$$
\text { Adjusted yield }=\text { Actual yield } \times \frac{100-M}{100-D}
$$

Where $M$, is the measured moisture content in grain and $D$ is the adjusted moisture content $(12.5 \%)$

Harvest Index was calculated as:

$$
H I(\%)=\frac{S Y}{B Y} \times 100
$$

Where $H I$ is harvest Index, $S Y$ is grain yield and $B Y$ is above ground dry biological yield

In order to know the economic feasibility of rain water harvesting it's used to analyze through benefit cost ratio. Economic feasibility is a very important factor in its acceptance by population. Rainwater harvesting systems can be economically viable and attractive to the beneficiaries. For the success or failure of the system, the socio-economic aspects are just as important as technical aspects of rainwater harvesting projects.

The project to be economically feasible, the benefit cost ratio should be more than one. To calculate the benefit-cost ratio, all inputs and outputs should be identified, quantified and valued (Gittenger, 1982). Mathematically the benefit-cost ration can be expresses as (Gittenger, 1982).

$$
B C R=\frac{\text { Total Benefit }}{\text { Total Cost }}
$$

Economic analysis was made following CIMMYT methodology (CIMMYT, 1998). The cost of $100 \mathrm{~kg}$ urea (1087ETB), 100kg DAP (1415 ETB) were used for the benefit analysis. The analysis of data in relation to different factors of production under test viz: the methods of plough for wheat crop were computed in terms of: (1) Gross returns (ETB $\mathrm{ha}^{-1}$ ) from total economic produce and by products obtained from the crops included in the cropping system are calculated based on the local market prices at harvest, (2) Net return (ETB ha ${ }^{-1}$ ) (Gross return - cost of production), (3) Cost of production (ETB ha-1), (4) Benefit Cost ratio (Gross return/ cost of Production), (5) Per day productivity (kg ha $^{-1}$ ), (Grain Yield/Crop duration), (6) Return/Birr Investment (Net return/Production Cost) were determined.

All agronomic data collected were subjected to the analysis of variance (ANOVA) as per the design used in the experiment using statistical software SAS (2002) version 9.1. Means that were significantly affected by the treatments were separated using the Least Significant Difference (LSD) test at 5\% level of significance.

\section{RESULTS AND DISCUSSION}

\section{Rain water harvesting efficiency evaluation}

The Technical Performance Evaluation indicators showed that in Ginchi district rain water harvesting pond theRunoff Harvesting Efficiency (RHE) wasless. This is mainly due to the land which is planned for catchment was very large compared to the water in the storage. This indicated that the delineated catchment was more than sufficient or not proportional to crop land or irrigation water requirement.

Table 1: Technical performance efficiency on

\begin{tabular}{|c|c|c|c|c|c|}
\hline $\begin{array}{l}\dot{\mathrm{z}} \\
\dot{\omega}\end{array}$ & $\sum_{=}^{\infty}$ & 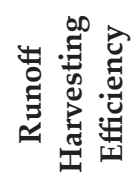 & 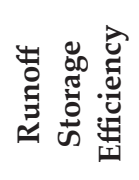 & 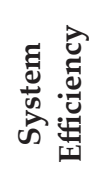 & 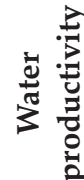 \\
\hline 1 & Pond & 0.029 & 0.84 & 0.02 & 17.95 \\
\hline
\end{tabular}
rainwater harvesting systems (Adapted from cropwat .net 2015

RWHS; Rain water harvesting system.

Runoff Storage Efficiency (RSE) in all systems was less than one due to evaporation losses $(5 \mathrm{~mm})$. The rain water harvesting collected in the pond were solve the problem of downstream farmers which 
is affected by excess water comes from the above farm land. During the 2015/16 rainy season there was shortage of rain in Ethiopia due to El Niñorain water harvesting in Ginchi district were solve the water shortage and rain irregularity in study area.

\section{Days to $50 \%$ flowering}

Planting method significantly affected mean number of days to heading $(\mathrm{P}<0.05)$ (Table 2). The control and shurube planting method delayed days to heading, as compared to the shaga and Aybar BBM treatments. This indicates the effect of excess soil moisture in delaying the number of days required to reach heading in wheat crop. Presence of excess moisture in the root zone of wheat had reduced the availability of oxygen essential for respiration of roots. In addition, excess moisture had resulted in reduced intake of essential nutrients, which had a negative impact on ear head formation of wheat. Reports of similar work on other durum wheat varieties also indicated a delay of 3 to 6 days depending on the cultivars under excess soil moisture condition (Bemnet et al. 2003). A delay of days to heading due to excess soil moisture was also reported for winter wheat (Belford, 1981).

Table 2: Mean values of crop component traits for wheat grown at Ginchi in 2015

\begin{tabular}{ccc}
\hline Treatment & $\begin{array}{c}\text { Days to } 50^{\%} \\
\text { flowering }\end{array}$ & $\begin{array}{c}\text { Days to } \\
\text { maturity }\end{array}$ \\
\hline Aybar BBM & $70.9^{\mathrm{c}}$ & $93^{\mathrm{c}}$ \\
Shaga & $73.75^{\mathrm{b}}$ & $95^{\mathrm{b}}$ \\
Shurube & $74.1^{\mathrm{b}}$ & $97^{\mathrm{b}}$ \\
Control & $76.1^{\mathrm{a}}$ & $99^{\mathrm{a}}$ \\
LSD (P<0.05) & 1 & 2.3 \\
CV (\%) & 1.96 & 2.35 \\
\hline
\end{tabular}

\section{Days to maturity}

Number of days to maturity was significantly affected $(\mathrm{P}<0.01)$ by planting methods, varieties (Table 3$)$. The results indicate that plants grown under the shurube and control took an additional more than one week time to reach physiological maturity as compared to plants grown under the AybarBBM. Based on the data AybarBBM, shaga and shurube takes 93, 95 and 97 days respectively to mature while control was takes 99 day to mature. This shows that the effect of water logging in restricted intake of essential nutrients, respiration of roots and other physiological activities, which resulted delay in the maturity Sharma and Swarup (1989) also reported a similar result. The result shows that under Aybar BBM the land can be used for double and triple cropping due to its possibility to harvest the crop early and thus enhances the farmer's income considering the substantial increase in cropping intensity (\%) and thereby multiplying the yield output per unit area of land. The 'Kekeba' variety of wheat used for first cropping was proper for this method due to the variety was harvested early compared to other variety.

Table 3: Mean values of crop growth attributes for wheat grown at Ginchi in 2015

\begin{tabular}{cccc}
\hline Treatment & $\begin{array}{c}\text { Plant } \\
\text { height }(\mathrm{cm})\end{array}$ & $\begin{array}{c}\text { Number } \\
\text { of seed per } \\
\text { head }\end{array}$ & $\begin{array}{c}\text { Tiller } \\
\text { number }\end{array}$ \\
\hline Aybar BBM & $83.53^{\mathrm{a}}$ & $48.1^{\mathrm{a}}$ & $4.6^{\mathrm{a}}$ \\
Shaga & $78.1^{\mathrm{ab}}$ & $37.03^{\mathrm{b}}$ & $3.56^{\mathrm{b}}$ \\
Shurube & $77.06^{\mathrm{ab}}$ & $27.8^{\mathrm{c}}$ & $3.16^{\mathrm{c}}$ \\
Control & $73.73^{\mathrm{b}}$ & $26.3^{\mathrm{d}}$ & $2.7^{\mathrm{d}}$ \\
LSD (P<0.05) & $\mathrm{NS}$ & 1.439 & 0.32 \\
CV $(\%)$ & 4.64 & 2.06 & 4.67 \\
\hline
\end{tabular}

NS= Non-Significant .

\section{Number of tillers per plant}

The number of effective tillers was markedly increased due to the treatments at $(\mathrm{P}<0.001)$ (Table 4 ). The number of productive tillers depends on genotype and environment and it is strongly influenced by planting density. Number of effective tillers is one of the yield components of wheat that contributes to high straw and biomass yield.

Accordingly, the highest number of effective tillers were recorded from treatment of BBM (4.6/plant) followed by Shaga (3.56/plant) while (3.16/plant) for shurube plough methods. The lowest plant tillers were recorded in control (2.7plant). The reason for higher effective tiller numbers under AybarBBM there were equal distribution of seed and fertilizer while in shaga method the land were exposed to erosion and the nutrients and seed were leached, whereas in the shurube and control there were dumping of soil over seed. This agrees with the findings of Bellford et al. (1985) that excess soil moisture suppressed spikes per $\mathrm{m}^{2}$ and spike length 
Table 4: Mean biomass, straw yield, kernel weight, grain yield and harvest index of wheat grown at Ginchi in 2015

\begin{tabular}{cccccc}
\hline Treatment & Biomass $\left(\mathbf{k g ~ h a}^{-1}\right)$ & Straw yield(g) & $\begin{array}{c}\text { Thousand seed } \\
\text { weight }(\mathbf{g})\end{array}$ & $\begin{array}{c}\text { Grain yield (kg/ } \\
\left.\text { ha }^{-1}\right)\end{array}$ & $\begin{array}{c}\text { Harvest Index } \\
\text { (\%) }\end{array}$ \\
\hline Aybar BBM & $22,780^{\mathrm{a}}$ & $642^{\mathrm{a}}$ & $44.75^{\mathrm{a}}$ & $4652.45^{\mathrm{a}}$ & $17.69^{\mathrm{a}}$ \\
Shaga & $20,576^{\mathrm{a}}$ & $480^{\mathrm{b}}$ & $41.88^{\mathrm{a}}$ & $3274.95^{\mathrm{b}}$ & $16.8^{\mathrm{a}}$ \\
Shurube & $18,325^{\mathrm{b}}$ & $356^{\mathrm{c}}$ & $40.05^{\mathrm{a}}$ & $2757.45^{\mathrm{c}}$ & $13.22^{\mathrm{b}}$ \\
Control & $16,277^{\mathrm{b}}$ & $289^{\mathrm{c}}$ & $35.64^{\mathrm{b}}$ & $2318.21^{\mathrm{d}}$ & $11.29^{\mathrm{b}}$ \\
LSD (P<0.05) & 2229.22 & 75.01 & 5.982 & 10.62 & 3 \\
CV (\%) & 23.43 & 8.49 & 7.37 & 6.56 & 10.2 \\
\hline
\end{tabular}

NS= Non-Significant .

considerably compared to better drained seedbed. These results indicated the higher sensitivity of spikes per $\mathrm{m}^{2}$ to water logging stress than spike length.

\section{Number of seed per head}

The number of seed per head was significantly affected in Aybar BBM treatment $(\mathrm{P}<0.05)$. Averaged over treatments, the Aybar BBM treatment gave significantly higher number of kernels per spike than the Shaga, Shurube and control treatments (Table 4). Based on the data, the highest value 48.1 seed/head was recorded in Aybar BBM plot whereas the control had the least value of $26.3 \mathrm{seed} / \mathrm{head}$ among all the treatments. This is in agreement with Bement et al. (2003) who stated that excess soil moisture suppresses number of kernels/spike. It is also supported by Greive et al. (1986) who pointed out that excess soil moisture during tillering and stem elongation leads to fewer tillers, more floral sterility and fewer grains per spike, and reduced individual weight.

\section{Thousand seed weight}

There were significant differences $(\mathrm{p}<0.05)$ among treatments in 1000 seed weight in AybarBBM and Shaga treatments whereas the control gave significantly lower thousand seed weight. Shurube and control had significantly lighter seed weight (Table 5) as compared to Aybar BBM and Shaga. The mean value for Aybar BBM and Shaga treatments were $44.75 \mathrm{~g}$ and $41.88 \mathrm{~g}$, respectively, whereas the value of Shurube and control were $40.05 \mathrm{~g}$ and $35.64 \mathrm{~g}$ respectively.

The reason for higher kernel weight in Aybar BBM plot was due to effective management excess water resulting in better uptake of nutrients and realization of agronomic potential of the improved seed.

\section{Straw yield}

The mean straw yield of wheat was significantly affected $(\mathrm{P}<0.05)$ by different tillage practices. When comparison was made among the treatments, significantly higher straw yield value was observed in Aybar BBM treatments and non- significantly higher straw yield was observed on Shaga and Shurube drainage system as compared to control. The difference due to treatments resulted in a significant effect on the straw weight during cropping season. The lowest weight of straw was resulted in control plot (Table 5). Several authors had reported increased yields of some crop grown on Vertisols due to the use of BBM as compared to flat seedbeds (Abiye et al. 1995; Srivastava et al. 1993; Teklu et al. 2006).

\section{Biomass}

The above ground biomass yield of wheat was significantly $(\mathrm{P} \leq 0.05)$ affected by treatments. The highest biomass yield (227.80 $\left.\mathrm{kg} \mathrm{ha}^{-1}\right)$ was obtained from Aybar BBM whereas the lowest biomass yield $\left(162,77 \mathrm{~kg} \mathrm{ha}^{-1}\right)$ was obtained from the control. Early sowing of wheat on Aybar BBM increased average biomass yield by over $63 \%$ as compared to the traditional late sowing on flat seedbeds (Teklu et al. 2013)

\section{Grain yield}

Results of analysis of variance indicated highly significant differences $(p<0.001)$ among the treatments in terms of grain yield (Table 5). The 2015 
Table 5: Partial budget analysis for Wheat

\begin{tabular}{cccccc}
\hline Treatment & Grain yield & $\begin{array}{c}\text { Adjusted yield } \\
\mathbf{( 1 0 \% )}\end{array}$ & Gross benefit & Total variable cost & $\begin{array}{c}\text { Net benefit } \\
\text { (ETB ha }^{-1} \mathbf{)}\end{array}$ \\
\hline Control & 2318.21 & 2086.39 & 17734.31 & 3401.27 & 14333.04 \\
Shurube & 2757.45 & 2481.71 & 21094.49 & 3480.34 & 17614.15 \\
Shaga & 3274.95 & 2947.46 & 25053.37 & 3573.49 & 21479.88 \\
Aybar BBM & 4652.45 & 4187.21 & 35591.24 & 4018.44 & 31572.80 \\
\hline
\end{tabular}

main rain season received below average rainfall. The differences in grain yield due to drainage could be even larger in seasons receiving average and above average rainfall. Several authors reported increased yields of some crops grown on Vertisols due to the use of the Aybar BBM as compared to the flat seedbeds (Abiye et al. 1995; Haque et al. 1996; Mohamed Saleem and Astatke, 1996). They suggested that the improvement in surface drainage and yield increase was spectacular during years of excessive rain. Abate et al. (1993) reported that from on-station trials for durum wheat (traditional local variety, Triticum durum L.), AybarBBMs compared with flatbed planting increased grain and straw yields by $60 \%$ and $36 \%$, respectively.

\section{Harvest index}

Harvest index was significantly affected by seedbed preparation method (Table 5). The difference between Aybar BBM andShaga was not statistically different whereas the differences between these treatments with Shurube and Control were statistically significant. Similar results were also reported by Jutzi and Mesfin, (1987).

\section{Double cropping}

Double cropping practicewas done in all experimental plots. Due to logistical reasons it was not possible to dig ponds for each treatment. However, due to below average rainfall during the season it was possible to practice double cropping on all the treatments. With average and above average rainfall it may not be possible to practice double cropping in the controls because either the wheat crop could face complete crop failure or the difference in days to maturity would be much larger than what was observed making it impossible to practice double cropping. Moreover, water harvested from drained fields would be more than that from control.
Overall results demonstrate that grain yields of chickpea grown as double cropping using residual moisture and $13 \mathrm{~m}^{3}$ water were consumed as supplementary irrigation from the pond and from this production $900 \mathrm{~kg}$ of chickpea from the same area were obtained. Double cropping adds nitrogen to the soil especially when the second crop is a nitrogen fixing crop like legumes. According to Campbell (1997) Chickpea (Cicer arietinum L.) is important food legume planted in the post-rain season (September/October) relying on residual moisture on major soil type. There are reports of complete failure of the second crop at Ginchi and elsewhere under rainfed conditions (e.g. Tanner et al. 1991), which makes the use of ponds beneficial. Baye and Berhe (2011) reported possibility of double-cropping of barley with chickpea on residual moisture substituting for the traditional fallow-chickpea cropping system on Vertisols in northwestern Ethiopia.

\section{Triple cropping}

Beet root and carrot were planted as triple-cropping under full irrigation using water stored in ponds. The results from triple cropping shows that $55 \mathrm{~m}^{3}$ water was consumed for this treatment and $157 \mathrm{~kg}$ of beet root and $164 \mathrm{~kg}$ of carrot yield from the same treatment area was obtained from the same field plot. Triple cropping was possible because of water stored in the pond. Studies on the possibility of using rain water harvesting for double and triple cropping in Ethiopia, is lacking. This calls for more research on double and triple cropping as part of vertisol management package.

\section{Benefit cost ratio (BCR) for rain water harvesting}

In the Ginchi district the benefit-cost analysis result for RWH project indicates the system was economically feasible. Economically, with respect 
to the rain water harvesting farming activities the benefit was greater than the cost. The result show that the general cost of for rain water harvesting farming was 5214.8ETB while the benefit gained from this project was 16382 ETB the overall cost benefit ratio for study area was 11167.2ETB. Beside, the economic benefit the project also facilitates employment generation, reduction of community migration, and creation of skill as indirect benefits of rainwater harvesting systems development. Labor that would be spent in fetching water is also considered as the opportunity cost.

\section{Partial Budget analysis}

Due to water logging most of the Vertisol area in the Ethiopian highlands is left fallow during much of the rainy season there by making it difficult to achieve food security in the country. Farmers use various traditional methods to reduce water logging in vertisol farm plots. In order to address the problem several technological innovations have been introduced. However, until recently the adoption of such innovations has been very low. Results of our field research in Ginchi district showed that Aybar BBM, while addressing technical problems associated with previous version of the BBM, gave the highest grain and biomass yield of wheat crop.

To assess the cost and benefit associated with different treatments, the partial budget technique of CIMMYT (1988) was applied on yield of the wheat crop. The result of economic analysis showed that Aybar BBM recorded the highest net return of ETB 18643.63 with MRR value of 7068.62 which is economically feasible.

The problem of managing excess water removed from waterlogged fields has been solved by collecting the water in a pond and $13 \mathrm{~m}^{3}$ water consumed for second cropping as supplementary irrigation and $55 \mathrm{~m}^{3}$ water for triple cropping. From consumed water $900 \mathrm{~kg}$ of chickpea from second cropping as well as $157 \mathrm{~kg}$ of Carrot and $164 \mathrm{~kg}$ of beet root harvested from triple cropping at the same field plot. From

Thus, in the Ginchi district, where wheat is traditionally produced, the use of Aybar BBM is not only technically viable, but also economically promising and ecologically desirable.
Based on the findings of this study, the following recommendations can be made:

- The findings of the study indicate that significant additional effort should be dedicated to the design and implementation of the extension campaigns for promoting new agricultural technologies like Aybar BBM to solve the problem of water logging during the rainy season.

- Promotion of water harvesting techniques for a better utilization of the drained excess water such as irrigation of a third crop is recommended.

- A watershed approach to the application of the Aybar BBM technology would be more beneficial.

- Further research in different localities is required to verify the conclusions of our research.

\section{REFERENCES}

Abebe M. and Jutzi, S. 1993. The Jiont Project on Vertisols management: Retrospect and Prospects. In: Tekalign Mamo, Abiye Astatke, K.L. Srivastava and Asgelil Dibabe (eds.) Improved crop livestock production in Ethiopian Highlands: Syntehsis Report 1986-92: Adds Ababa, Ethiopia.

Abebe, M. 1982. Uses of improved seedbed preparation and fertilizer as an alternative to soil burning.Ethiopian Journal of Agriculture Science, 1(1): 1-10.

Abebe, M. 1998. Nature and management of Ethiopian soils. Alemaya, University of Agriculture. 270p.

Alem, G. 1999. Rainwater Harvesting Concepts and Issues. Paper presented at the founding conference of the Ethiopian Rainwater Harvesting Institute. December 17, 1999, Addis Ababa.

Asamenew, G. Jutzi, S.C., Tedla, A. and McIntire, J. 1988. Economic evaluation of improved Vertisol for food crop production in the Ethiopian highlands. In Jutzi, S.C. et al. (ed.), Management of Vertisols in sub-Saharan Africa. Proceedings of a conference held at ILCA, Addis Ababa, Ethiopia, 31 August - 4 September, 1987. ILCA, Addis Ababa, p. 263-283.

Asamenew, G., Beyene, H., Hailu, A. and Negatu, W. 1993. Technology Improved Management of Vertisols for Sustainable Crop and Livestock Production in the Ethiopian Highlands, Synthesis Report, 087581, pp. 028, 035.

Asamnew G. and Saleem, M. 1992. Farmer participatory roles in technology development and transfer: A case study from on-farm Vertisol Technology experience in Ethiopia. In: Stephen S. and A. Reece (eds.). Proceedings 
of the Workshop on Farmers' Participatory Research held in Addis Ababa, Ethiopia.

Astatke, A. Reed, J.D. and Butterworth, M.H. 1986. Effect of diet restriction on work performance and weight loss of Highland Zebu and Friesian $\times$ Boran oxen. ILCA Bulleting 23, 11-14. ILCA, Addis Ababa, Ethiopia.

Astatke, A., Bunning, S. and Anderson, F. 1996. Pond construction with animal power in the Ethiopian highlands: A manual. ILCA. Addis Ababa, Ethiopia, pp. 38.

Astatke, A., Muhamed-Saleem, M.A. and ElWakeel, A. 1995. Soil water dynamics under cereal and forage legume mixtures on drained Vertisols in the Ethiopian highlands. Agriculture. Water Manage.

ATA. 2013. Annual report. Transforming Agriculture in Ethiopia, pp. 76.

Awlachew, S.B., Hagos, F., Amede, T. and Loulseged, M. 2011. Best bets technologies for improving agricultural water management and system intensification in Ethiopia.

Awlachew, S.B. and Merrey, D.J. 2006. Assessment of Small Scale Irrigation and Water Harvesting in Ethiopian Agricultural Development. International Water Management Institute (IWMI), Addis Ababa.

Bekele, G. 1987. Evaluation of Ethiopian durum wheat for waterlogging stress tolerance. Ethiopian Journal Agriculture Science, 19: 64-93.

Bekele, G., Tessema, T., Becker, H.C. and Meker, A. 1993. Variation and interrelationships of Response of wheat (Triticum aestiuum).

Belayneh, H. 1987. The effects or drainage systems, drainage spacings and fertilizer on seed yield and other character+rs of wheat, teff, and chickpea on heavy soils of Ginchi. Ethiopian Journal Agriculture Science, 8(2): 85-94.

Bellford, R.K. 1981. Response of winter wheat to prolonged water logging under outdoor condition. Journal Agriculture Science (Camb.), 97: 557-568.

Bellford, R.K., Cannel, R.Q. and Thomson, R.J. 1985. Effect of single and multiple waterlogging on the growth and yield of winter wheat on clay soil. Journal of Science food Agriculture, 36: 142-156.

Bureau of Agriculture (BOA), Oromia Region. 2003. Rainwater harvesting technologies in Oromia Region, Finfine, Ethiopia, pp. 157

Campbell, C.G. 1997. Grass pea, Lathyrus sativus L. Promoting the conservation and use of underutilized and neglected crops. 18. Gatersleben: Institute of Plant Genetics and Crop Plant Research and Rome: International Plant Genetic Resources Institute, pp. 92.

CIMMYT (International Maize and Wheat Improvement Center). 1988. From Agronomic data to Farmer Recommendations: An Economics Training manual. Completely Revised Edition, Mexico, DF.79p.

CIMMYT (International Maize and Wheat Improvement Center). 2011. Wheat - Global alliance for improving food security and the livelihoods of the resource-poor in the developing world. Proposal submitted by CIMMYT and ICARDA to the CGIAR Consortium Board.
CSA (Central Statistical Agency). 2010. Crop production forecast sample survey. Report on Forecast of Area and production of Major Crops (for rural private peasant holdings). Statistical Bulletin, 271: 18-19.

CSA (Central Statistical Authority). 2013. Agricultural Sample Survey 2007/2008. Report on Agricultural Practice (private peasant holdings, main season) Statistical Bulletin 132. Addis Ababa, Ethiopia.

Debele, B. 1985. The vertisols of Ethiopia, their properties, classification and management. pp.31-54. In: fifth meeting of Eastern Africa soil correlation and land evaluation SubCommittee, Wad Medani, Sudan, 4-10 December 1983, World Soil Resources Report No.56. FAO, Rome.

Demissie, A. and Hailemariam, G. 1989. Wheat genetic resource in Ethiopia. pp. 33-46. In: Hailu Gebremariam, Tanner D.G. and Mengistu Huluka (eds.). Wheat research in Ethiopia .A historical perspective. IAR/CIMMYT, Addis Ababa, Ethiopia.

Demissie, A. and Hailemariam, G. 1991. Ethiopia wheat germplasm collection, conservation, evaluation and utilization. pp. 327-334. In: Tanner, D.G., M. Van Ginkel and W. Muang. The Sixth Regional Wheat Workshop for Eastern, Central and Southern Africa. CIMMYT, Mexico.

Desta, L., Carrucci, V., Wendemagene, A. and Abebe, Y. 2005. Community based participatory watershed development: a Guideline Ministry of agriculture and Rural Development Addis Ababa, Ethiopia.

Ding, N. and Musgrave M.E. 1995. Relationship between mineral coating on roots and yield performance of wheat under waterlogging stress. Journal of Experiment Botany, 46, 939-945.

Erkossa, T. 1997. Effect of surface drainage methods on soil and water conservation, root zone water balance and wheat performance, M.Sc. thesis, Wageningen Agricultural University, Wageningen, The Netherlands.

Erkossa, T. 1998. Effectiveness of land preparation methods for surface drainage. Water. Arbaminch Water Technology Journal 2: 21-28.

Erkossa, T., Menker, M. and Betrie, G.D. 2010. Effects of bed width and planting date on water productivity of wheat grown on vertisols in the Ethiopian highlands Irrigation and Drainage Journal.

Erkossa, T., and Kebede, S. 2001. Soil Erosion and Conservation in Ethiopian Vertisols. P.107-114.In: Paulos D. Asgelil D., Asfaw Z., Gezahegn A. and Abebe, K. (eds) Advances in Vertisols Management in Ethiopian Highlands.

Erkossa, T., Gizachew, A. and Stahr, K. 2004. Land preparation methods efficiency on the highland Vertisols of Ethiopia. Irrigation and Drainage, 53: 69-75.

Erkossa, T., Haileslassie, A. and MacAlister, C. 2013. Enhancing farming system water productivity through alternative land use and improved water management of rainfed agriculture in Vertisol areas. In: Wolde Mekuria. (ed). 2013. Rainwater management for resilient livelihoods in Ethiopia: Proceedings of the Nile Basin Development Challenge science meeting, Addis Ababa, 9-10 July 2013. 
NBDC Technical Report 5. Nairobi, Kenya: International Livestock Research Institute.

Erkossa, T., Stahr, K. and Gaiser, T. 2006. Soil tillage and crop productivity on a Vertisol in Ethiopia highlands: Soil tillage research, pp. 85.

FAO/LUPRD (Food and Agriculture Organization/Land Use Planning and Rural Development). 1984. Ethiopia: geomorphology and soils. AG: DP/ETH/78/003. Field Document 3, Addis Ababa.

FAOSTAT. 2009. Food and Agriculture Organization of the United Nations online database http://faostat.fao.org.

Gashawbeza, B., Yaekob, A., Zemede, A., Kifetew, J. and Tadesse, T. 2003. Fertilizer $\mathrm{N}$ effects on yield and grain quality of durum wheat. Tropical Agriculture (Trinidad) 80(3): 146-151.

Gebremariam, H. 1991. Wheat production and research in Ethiopia. In Hailu Gebremariam, D.G. Tanner,and M. Hulluka (eds.). Wheat Research in Ethiopia: A Historical Perspective. Addis Ababa, Ethiopia: IAR/CIMMYT, pp. 1-16.

Gittenger, J.P. 1982. Economic Analysis of Agricultural projects. Second Edition, EDI Serious in Economic Development. USA., pp. 457.

Hailemariam, T. 2012. Characterization, Economic analysis and performance evaluation of rainwater harvesting systems in Minjar-Shenkora Woreda, North Shoa Zone. A Thesis Submitted to the School of Graduate Studies, Through School of Natural Resource and Environmental Engineering Haramaya University.

Haque, I. and Jutzi, S.C. 1984. Effects of improved drainage and fertilization on the growth of Italian rye grass and oats on a soil with vertic properties at Debre Brehan, Ethiopia. ILCA News letter (Ethiopia) v. 3(4): 5-6.

Haque, I., Lupwayi, N.Z. and Luyindula, N. 1996. Inoculation and phosphorus effects on Desmodium intortum and Sesbania sesban in the Ethiopian highlands. Agric., Ecosys. Environ., 56: 165-172.

IAR (Institute of Agricultural Research). 1975. Study of simple drainage systems in a poorly drained Pellic Vertisol pp. 147-153. Holleta-Genet research station progress report 1972/73. Addis Ababa, Ethiopia.

ILCA/IAR/AUA. 1990. International Livestock Center for Africa / Institute of Agriculture Research/Alemaya University of Agriculture, Joint Vertisol Project Report. ILCA, Addis Ababa, Ethiopia, 72p. In: Tekalign Mamo, Abiye Astatke, K.L. Srivastava and Asgelil Dibabe (eds.) Improved crop.

Jackson, M.B. and Drew, M.C. 1984. Effects of flooding on growth and metabolism of herbaceous plants, pp. 47-128. In: Flooding and Plant Growth.

Jutzi, S.C. and Abebe, M. 1987. Improved agricultural utilization of vertisols in the Ethiopian highlands an international approach, pp. 173-183. In: Proceeding of First Regional Seminar on Management of Vertisols under Semi- Arid Conditions. Nairobi, Kenya, 1-6 December 1986.
Jutzi, S.C., Anderson, F.M. and Abiye Astatke. 1986. Low cost modifications of the traditional Ethiopian type plough for land shaping and surface drainage of heavy clay soils: Preliminary results from on-farm verifications. In: Animal power in farming system, ed P. Starkey and F. Ndiane, Eschborn, Germany: German Technical Agency.

Jutzi, S.S., Haque, I., Mcintire, J. and Stares, J.E. 1988. Management of Vertisols in sub-Saharan Africa. Proceedings of a conference held at ILCA, Addis Ababa, Ethiopia, and 31 August to 4 September, 1987. International Livestock Centre for Africa, Addis Ababa, Ethiopia. 435p.

Mamo, T., Astatke, A., Srivastavn, K. L. and Dibabe, A. 1993. Improved management of vertisols for sustainable crop-livestock production in the Ethiopian highlands. Synthesis Report 1986-92. Technical Committee of the Joint Vertisol Project, Addis Ababa, Ethiopia.

Morgan, W.T.W. 1972. The exploitation of the East-African environment. In: ed. W.T.W. Morgan, Africa: Its People and Resources. Oxford University Press, Oxford, UK.

Mulatu, B. and Lakew, B. 2011. Barley research and development in Ethiopia - an overview. In: Mulatu B, Grando S, editors. Barley research and development in Ethiopia. Proceedings of the $2^{\text {nd }}$ National Barley Research and Development Review Workshop; 2006 Nov 28-30. Holetta: HARC.

Ngigi, S.N. 2003. Rainwater harvesting for supplemental irrigation: promising technology for enhancing food security in semi-arid areas, Proceedings of $10^{\text {th }}$ IRCSA Conference. 10-14 September 2001, Manheim, Germany, pp. 1-5.

Rutherford, A.S. 2008. Broad bed maker technology package innovations in Ethiopian farming systems: An ex post impact assessment. Research Report 20. ILRI (International Livestock Research Institute), Nairobi, Kenya, pp. 89 pp.

Rutherford, A.S., Odero, A.N. and Kruska, R.L. 2001. The role of the broadbed maker plough in Ethiopian farming systems: An ex post impact assessment study. ILRI Impact Assessment Series 7. ILRI (International Livestock Research Institute), Nairobi, Kenya, pp. 156.

Saleem, M.A. 1995. Fragile East African highlands: a development vision for smallholder farmers in the Ethiopian highlands. Outlook Agriculture, 24(2): 111-116.

Saleem, M.A. and Astatke, A. 1996. Options to intensify cropland use for alleviating smallholder energy and protein deficiencies in the East African Highlands. Field Crops Research, 48: 177-184.

SAS (Statistical Analysis System). 2002. SAS Version 9.1.3.SAS Institute Inc., Cary, NC, USA.

Sharma, D.P. and Swarup, A. 1989. Effects of short- term flooding on growth, yield and mineral composition of whe, at on sodic soil under field condition. Plant and Soil, 107: $137-143$

Srivastava, K.L., Astatke, A., Mamo, T., Regassa, H. and Kidanu, S. 1993. Land, Soil and Water management. In: 
Improved management of Vertosols for sustainable croplivestock production in the Ethiopian highlands: Synthesis report 1986-92 (by Tekalign Mamo, Abiye Astatke, K.L. Srivastava, Asgelil Dibabe). Technical committee of the joint Vertisol project, Addis Ababa, Ethiopia.

Suresh, R. 1997. Soil and Water Conservation Engineering. Standard Publishers Distributors, India, pp. 45-85.

Tanner, D.G., Gorfu, A. and Zewde, K. 1991. Wheat agronomy research. In: Gebre-Mariam H, Tanner DG, Hulluka $\mathrm{M}$, editors. Wheat research in Ethiopia: a historical perspective. Addis Ababa: IAR/ CIMMYT.

Tedla, A. Mohamed-Saleem M.A., Mamo, T., Tadesse, A. and Duffera, M. 1993. Grain, fodder and residue management. In: Tekalign Mamo, Abiye Astatke, Srivastava K.L. and Asgelil Dibabe (eds), Improved management of Vertisols for sustainable crop-livestock production in the Ethiopian highlands: Synthesis report 1986-92. Technical Committee of the Joint Vertisol Project, Addis Ababa, Ethiopia, pp. 103-137.
VanReeuwijk, L.P. 1992. Procedures for soil analysis, $\left(3^{\text {rd }}\right)$ ed. International Soil Reference and Information Center (ISRIC), Wageningen, the Netherlands, pp. 34.

Virmani, S.M. 1988. Agroclimatology of the Vertisols and vertic soils areas of Africa. In: Mannagement of Vertisols in sub-Saharan Africa. Proceedings of conference held at ILCA (Addis Ababa, 1987). Addis Ababa,Ethiopia: ILCA.

Yimer, A. 2003. Guidelines on water harvesting techniques. World Food Program (WFP). Addis Ababa, Ethiopia, pp. 141. 
